\title{
Phosphorus deficiencies invoke optimal allocation of exoenzymes by ectomycorrhizas
}

\author{
Justin A. Meeds ${ }^{1} \cdot$ J. Marty Kranabetter $\mathbb{1}^{2} \cdot$ leva Zigg $^{1,3} \cdot$ Dave Dunn $^{4} \cdot$ François Miros ${ }^{3} \cdot$ Paul Shipley $^{3} \cdot$ \\ Melanie D. Jones ${ }^{1}$
}

Received: 19 July 2020 / Revised: 20 November 2020 / Accepted: 30 November 2020 / Published online: 8 January 2021

(c) Crown 2020. This article is published with open access

\begin{abstract}
Ectomycorrhizal (EM) fungi can acquire phosphorus (P) through the production of extracellular hydrolytic enzymes (exoenzymes), but it is unclear as to the manner and extent native EM fungal communities respond to declining soil $\mathrm{P}$ availability. We examined the activity of six exoenzymes (xylosidase, $N$-acetyl glucosaminidase, $\beta$-glucosidase, acid phosphomonoesterase, acid phosphodiesterase [APD], laccase) from EM roots of Pseudotsuga menzesii across a soil podzolization gradient of coastal British Columbia. We found that APD activity increased fourfold in a curvilinear association with declining inorganic P. Exoenzyme activity was not related to organic P content, but at a finer resolution using ${ }^{31} \mathrm{P}-\mathrm{NMR}$, there was a strong positive relationship between APD activity and the ratio of phosphodiesters to orthophosphate of surface organic horizons (forest floors). Substantial increases (two- to fivefold) in most exoenzymes were aligned with declining foliar $\mathrm{P}$ concentrations of $P$. menzesii, but responses were statistically better in relation to foliar nitrogen $(\mathrm{N}): \mathrm{P}$ ratios. EM fungal species with consistently high production of key exoenzymes were exclusive to Podzol plots. Phosphorus deficiencies in relation to $\mathrm{N}$ limitations may provide the best predictor of exoenzyme investment, reflecting an optimal allocation strategy for EM fungi. Resource constraints contribute to species turnover and the assembly of distinct, well-adapted EM fungal communities.
\end{abstract}

\section{Introduction}

Phosphorus (P) availability can be a fundamental constraint to primary productivity in many ecosystems, especially older soils where total P typically decreases and the ratio of organic

Supplementary information The online version of this article (https:// doi.org/10.1038/s41396-020-00864-z) contains supplementary material, which is available to authorized users.

$\triangle$ J. Marty Kranabetter

Marty.Kranabetter@gov.bc.ca

1 Biology Department, University of British Columbia, Okanagan Campus 1177 Research Road, Kelowna, BC V4V 1V7, Canada

2 British Columbia Ministry of Forests, Lands and Natural Resource Operations, P.O. Box 9536 Stn Prov Govt, Victoria, BC V8W 9C4, Canada

3 Chemistry Department, University of British Columbia, Okanagan Campus 3187 University Way, Kelowna, BC V4V 1V7, Canada

4 Natural Resources Canada, Pacific Forestry Centre, 506 Burnside Road West, Victoria, BC V8Z 1M5, Canada
$\mathrm{P}\left(\mathrm{P}_{\mathrm{o}}\right)$ to inorganic $\mathrm{P}\left(\mathrm{P}_{\mathrm{i}}\right)$ increases [1]. P-depleted soils can also be found with podzolization under wetter climates, where precipitation encourages the solubilization of primary mineral $\mathrm{P}$, accelerates conversion of $\mathrm{P}_{\mathrm{i}}$ to $\mathrm{P}_{\mathrm{o}}$ by microorganisms, and increases the formation of secondary mineral $\mathrm{P}$, thereby reducing the availability of orthophosphate for uptake by roots and microbes [2]. $\mathrm{P}$ deficiencies are also starting to occur in European and North American temperate forests affected by $\mathrm{N}$ pollution and climate change $[3,4]$.

Members of the Pinaceae are obligately symbiotic with ectomycorrhizal (EM) fungi [5]. In these trees, virtually all of the fine absorptive roots form ectomycorrhizas; hence, the EM roots can be considered the nutrient-absorbing organs of these plants and the ability of the fungi to absorb nutrients will influence plant nutrient status [6-8]. EM fungi use several strategies to enhance mobilization of both inorganic and organic P [9-11]. Of particular importance for $\mathrm{P}$ mobilization is extracellular hydrolytic enzymes (exoenzymes) that adhere to the surfaces of mantle and extramatrical (i.e., external to the mantle) hyphae of ectomycorrhizas [8, 12-14]. Two key types of exoenzymes involved in the direct hydrolysis of $\mathrm{P}$ from phosphoesters of 
soil organic matter are acid phosphomonoesterases (APMs) and phosphodiesterases [15, 16]. While phosphodiesterase activities of ectomycorrhizas have been little studied, increases in phosphomonoesterase activity of litter colonized by EM fungi have been associated with loss of $P$ from the litter and accumulation of $\mathrm{P}$ in EM seedlings [17, 18]. Other fungal exoenzymes, such as cellobiohydrolase, $\beta$ glucosidase (GU), $\beta$-glucuronidase, xylosidase $(\mathrm{X})$, and laccase (LAC), play an indirect role in $\mathrm{P}$ acquisition by degrading cell walls in plant and fungal necromass, thereby providing access to the nutrients within [8, 19]. EM fungal species differ considerably in their expression of these enzymatic P-acquisition traits [20-22]; consequently, the species and diversity of EM fungi colonizing a plant influences its $\mathrm{P}$ content (e.g., [6, 23]).

EM fungal communities are highly diverse, with community composition filtered by deterministic processes (host and soil environment), along with some stochastic (dispersal) influences [24-26]. Evidence is accumulating that compatibility between soil chemistry and EM fungal nutrient acquisition traits, including extracellular enzyme activities and ion flux rates, is part of the environmental filter for EM fungal community assembly. This has been observed in forests with different host species [27], and over successional $[28,29]$ and nitrogen $(\mathrm{N})$ gradients [30]. Such congruence between functional traits and local edaphic conditions can arise through several mechanisms: species selection, adaptation of fungal populations to site conditions over time, or phenotypic plasticity (i.e., acclimation; [27]). Site-specific EM fungal communities possessing traits that increase access to growth-limiting nutrients are expected to contribute to the overall fitness of the plant partner and, hence, the symbiosis [31]. Indeed, the ability of seedling genotypes to survive on a specific soil is mediated, at least in part, by being able to associate with the EM fungi adapted to those soils [32]. If tree genotypes are not able to associate with the locally adapted EM fungi, their growth may be impaired relative to local tree genotypes [33]. As more forest regions become P-limited, the availability of EM fungal communities adapted to accessing specific form of soil $\mathrm{P}$ will be important for survival and/or migration of trees; however, little is known about the natural variation in P-acquisition strategies exhibited by EM fungal communities as sources of $\mathrm{P}$ change across landscapes.

Although we have focussed on response to soil P levels alone, a potentially more comprehensive evaluation of EM fungal response to nutrient deficiencies would be through resource stoichiometry, particularly the simultaneous constraints of $\mathrm{N}$ and $\mathrm{P}$ (expressed as an $\mathrm{N}: \mathrm{P}$ ratio) on metabolism and growth [34]. The balance of $\mathrm{N}$ and $\mathrm{P}$ limitations is particularly relevant to the principle of optimal allocation, which suggests that mycorrhizal fungi will preferentially allocate energy toward acquiring the resources that are most limited in supply $[31,35,36]$. This principle has been widely established experimentally for decomposer biota such as bacteria and saprotrophic fungi [37]. For example, microbes will maximize $\mathrm{N}$-acquiring enzymes under low $\mathrm{N}$ : $\mathrm{P}$ resources such as leaf litter with limited $\mathrm{N}$ mineralization rates, but then shift to $\mathrm{P}$-acquiring enzymes under high $\mathrm{N}: \mathrm{P}$ litter where $\mathrm{N}$ supply is less constraining [38]. The sensitivity of exoenzyme production to both $\mathrm{N}$ and $\mathrm{P}$ supply, rather than $\mathrm{P}$ alone, could therefore broaden our perspectives on stand nutrition and the rationale behind nutrient acquisition strategies of mycorrhizal fungi.

Here we report on P-acquisition exoenzyme activities associated with ectomycorrhizas along a podzolization gradient of coastal forests across Vancouver Island, where there has been a considerable depletion of orthophosphate and primary mineral $\mathrm{P}$, alongside an accumulation of $\mathrm{P}_{\mathrm{o}}$ [7]. Our goal was to test whether EM fungal $\mathrm{P}$-acquisition strategies changed along this soil $\mathrm{P}$ gradient, while holding host tree species and tree age constant. We measured the activity of a series of exoenzymes found on the surfaces of EM root tips of coastal Douglas-fir (Pseudotsuga menzesii var. menzesii) stands and relate the exoenzyme concentrations to soil $\mathrm{P}$, including inorganic $\mathrm{P}$ as well as organic fractions revealed by ${ }^{31} \mathrm{P} \mathrm{NMR}$. We hypothesized that activities of all exoenzymes would be higher in strongly podzolized soils, where $\mathrm{P}_{\mathrm{o}}$ contributes the majority of total P. In addition, we tested whether exoenzyme activities were predominantly related to soil $\mathrm{P}$ availability or whether a combined index with $\mathrm{N}$ (as soil or host $\mathrm{N}: \mathrm{P}$ ) would better reflect allocation strategies by EM fungi. Last, we explored whether the highest levels of phosphatase activities would be associated with EM fungal species restricted in their distribution to the podzolized, low-P soils. Results of our study will provide further insights into the manner and extent EM fungal communities of a single tree host have responded to declining soil $\mathrm{P}$ availability during soil development.

\section{Methods}

\section{Site descriptions}

We selected ten locations across an $\sim 100-\mathrm{km}$ extent of southern Vancouver Island (British Columbia, Canada) that encompassed a podzolization gradient driven by an orographic rainshadow, as described in ref. [7]. The sites were selected to capture a gradient in soil $\mathrm{N}$ and $\mathrm{P}$ availability, ranging from upland mesotrophic stands in both dry (referred to as "Upland Brunisol," $N=4$ ) and wet ("Upland Podzol," $N=4$ ) coastal forests, along with moist, nutrientrich soils in wet coastal forests ("Lowland Podzol," $N=4$ ). We established one plot $(25 \times 25 \mathrm{~m}$ in size $)$ at each site, with the exception of Branch 167 and 247, where the complex topography enabled us to sample both an Upland and 
Lowland Podzol plot ( $400 \mathrm{~m}$ apart at both sites). All locations had second-growth $P$. menzesii stands that ranged in age from 40 to 60 years.

\section{Soil and foliar attributes}

Soil and foliar data were first reported in ref. [7], with the additions here of Bray $\mathrm{P}$ and ${ }^{31} \mathrm{P}$ NMR spectroscopy conducted later on the same soil samples. Total soil $\mathrm{P}\left(\mathrm{P}_{\mathrm{t}}\right)$ was the sum of inorganic $\left(\mathrm{P}_{\mathrm{i}}\right)$ and organic phosphorus $\left(\mathrm{P}_{\mathrm{o}}\right)$ concentrations as determined by the ignition method using a sulfuric acid $(0.5 \mathrm{M})$ digest [39]. $\mathrm{P}$ in soil solution, or weakly adsorbed to soil colloids, was determined by a Bray $\mathrm{P}$ extraction [39]. One representative forest floor sample (the partly and well-decomposed horizons of the surface organic layer [40]) from two plots of each soil type (Upland Brunisol, Upland Podzol, Lowland Podzol) was selected for ${ }^{31} \mathrm{P}$ NMR analysis following [41]. Only forest floor samples were analyzed because mineral soil samples did not have high enough $\mathrm{P}$ concentrations to detect peaks. Briefly, samples were shaken in $0.5-\mathrm{M} \mathrm{NaOH}$ and $0.1-\mathrm{M}$ disodium EDTA solution for $4 \mathrm{~h}$, centrifuged, filtered to $6 \mu \mathrm{m}$, freezedried, and re-dissolved in minimum amount of deuterated solvent. Dimethyl methyl phosphonic acid was used as an internal standard. Proton-decoupled spectra were obtained on a Varian $400-\mathrm{MHz}$ spectrometer and processed using MestreNova v12.0 software (Supplementary Method 1).

\section{Sampling of EM root tips}

Sampling of EM roots took place over 3 weeks, from late May to mid-June 2018. At the start of each week, we sampled four plots that included one or two replicates of each soil type. Seven soil cores, $\sim 15-\mathrm{cm}$ wide and $15-\mathrm{cm}$ deep, were collected randomly from each plot using a long knife and pruning clippers. The soil cores included both forest floor and mineral soil substrates, and many EM roots were found near the interface of these two substrates. Soil cores were transported on ice to the lab for overnight storage at $4{ }^{\circ} \mathrm{C}$. Exoenzyme assays took place over the subsequent 3 days of each sample week.

\section{Microplate exoenzyme activity assays}

Exoenzyme activity assays (Supplementary Method 2) were modified from protocols of refs. [20, 42, 43] and the Kennedy lab website (https://cbs.umn.edu/kennedy-lab/ protocols). Starting the day after field sampling, the soil cores of each plot were examined and fresh, vigorous clusters of EM root tips of the same morphology were selected and excised to proceed with exoenzyme activity assays. Distinct EM morphotypes were taken from each soil sample to ensure a wide representation of EM fungal species per plot, although some common morphotypes (e.g., Cenococcum) were selected from multiple soil samples within a plot. We retrieved between 10 and 16 morphotype clusters per plot, for a total of 157 clusters across all 12 plots.

Surface debris and soil particles were carefully removed from the EM root tips under a dissecting scope. Emanating hyphae were kept intact as much as possible during cleaning for those mantles with short-, medium- and long-distance exploration types [44]. Five individual EM root tips from each cluster were removed for the exoenzyme assay. The exoenzyme activities were assayed in series on each root tip (rinsing the roots between assays) in the following order: xylosidase (X), $N$-acetyl glucosaminidase (NAG), $\beta$-GU, APM, acid phosphodiesterase (APD), and LAC. The exoenzymes can be categorized as nutrient acquisition enzymes (NAG, APM, and APD), which hydrolytically cleave the target nutrient from the organic substrate, and lignocellulosic enzymes (X, GU, and LAC), which act to break down plant and fungal cell walls, in turn releasing the cellular contents for further action of nutrient acquisition enzymes. All the exoenzymes assayed are known to be cellwall bound [45], and thus, their activities are not dependent on a continued supply of fixed carbon from the plant. The activities recorded in the lab should be considered as an index of activities present at the time of sample collection, including those of microbial communities living on the surface of the mycorrhizal tips. The APD assay was modified from ref. [43] for use on root tips rather than soil, with volumes for all reagents adjusted for 96-well microplates. Following the fluorescence or absorbance assays, the root tips were then transferred into a clear 96-well microplate and scanned (Epson V800) for an estimate of projected area using WinRhizo software (Regent Instruments Inc., Québec, Canada) (Supplementary Method 2).

\section{Molecular analysis}

For each cluster that was assayed for exoenzymatic activity, 5-10 fresh EM tips were retained at $-80{ }^{\circ} \mathrm{C}$ for amplification of fungal DNA following a CTAB buffer extraction protocol (Supplementary Method 3). Fungal DNA was amplified using the universal ITS5/ITS4 or the basidiomycete-specific ITS1F/LR21 primer pairs. Forward and reverse sequences were aligned using Sequencher 4.7 (Gene Codes Corporation, Ann Arbor, MI USA). Sequences were BLAST-searched through the UNITE sequence database to assign Species Hypothesis based upon a $>98.5 \%$ similarity criteria [46].

\section{Data analysis}

Prior to analysis, the exoenzymatic activities for all five root tips per cluster were averaged. Soil nutrient content $(0-20-\mathrm{cm}$ 
Table 1 Average soil phosphorus concentrations of forest floor and mineral soil for each plot, including Bray $\mathrm{P}$, inorganic $\mathrm{P}\left(\mathrm{P}_{\mathrm{i}}\right)$ and organic $\mathrm{P}$ $\left(\mathrm{P}_{\mathrm{o}}\right)$ (SE in brackets).

\begin{tabular}{|c|c|c|c|c|c|c|c|}
\hline \multirow[t]{2}{*}{ Soil type } & \multirow[t]{2}{*}{ Plot } & \multicolumn{3}{|l|}{ Forest floor } & \multicolumn{3}{|l|}{ Mineral soil } \\
\hline & & Bray $\mathrm{P}\left(\mathrm{mg} \mathrm{kg}^{-1}\right)$ & $\mathrm{P}_{\mathrm{i}}\left(\mathrm{mg} \mathrm{kg}^{-1}\right)$ & $\mathrm{P}_{\mathrm{o}}\left(\mathrm{mg} \mathrm{kg}^{-1}\right)$ & Bray $\mathrm{P}\left(\mathrm{mg} \mathrm{kg}^{-1}\right)$ & $P_{\mathrm{i}}\left(\mathrm{mg} \mathrm{kg}^{-1}\right)$ & $P_{o}\left(\mathrm{mg} \mathrm{kg}^{-1}\right)$ \\
\hline \multirow[t]{4}{*}{ Upland Brunisol } & Salt Spring & 92.6 & 279 & 890 & $53.5(3)$ & $621(38)$ & 179 (34) \\
\hline & Niagara & $73.2(2)$ & $211(20)$ & $825(30)$ & $91.6(15)$ & $959(28)$ & 177 (17) \\
\hline & Sooke & 66.4 & 262 & 593 & $68.6(10)$ & 555 (138) & $138(60)$ \\
\hline & Mt Prevost & - & - & - & $118.4(22)$ & 903 (126) & $233(25)$ \\
\hline \multirow[t]{4}{*}{ Upland Podzol } & WC 1000 & $19.5(1.0)$ & $97(8)$ & 617 (72) & $1.7(0.3)$ & $46(14)$ & $163(46)$ \\
\hline & Fairy Lake & $20.0(0.8)$ & $104(14)$ & 549 (18) & $2.3(0.4)$ & $51(2)$ & $205(14)$ \\
\hline & Br. 247-59 & $24.1(2.3)$ & $140(22)$ & $554(11)$ & $2.4(0.5)$ & $31(9)$ & $134(11)$ \\
\hline & Br.167-126 & $14.9(2.3)$ & $103(11)$ & $401(34)$ & $2.3(0.4)$ & $235(23)$ & $290(15)$ \\
\hline \multirow[t]{4}{*}{ Lowland Podzol } & Br. 136 & $15.3(1.7)$ & $132(13)$ & 676 (119) & $3.1(0.1)$ & $103(18)$ & $401(29)$ \\
\hline & Br. 247-63 & $16.5(0.3)$ & $59(17)$ & 729 (297) & $6.2(1.5)$ & $136(10)$ & $416(80)$ \\
\hline & Klanawa & $19.6(0.7)$ & $132(9)$ & $2256(377)$ & $5.1(1.5)$ & $89(35)$ & $535(35)$ \\
\hline & Br. $167-105$ & $18.1(0.8)$ & $128(4)$ & 1860 (113) & $2.6(0.8)$ & $93(11)$ & $513(18)$ \\
\hline
\end{tabular}

Note some limited forest floor subsampling in Brunisols due to thin depths. mineral soil plus forest floor) was determined using bulk density, coarse fragment content, and forest floor depths as outlined in ref. [7]. Relationships between exoenzymatic activities and soil $\mathrm{P}$ characteristics $\left(\mathrm{P}_{\mathrm{i}}, \mathrm{P}_{\mathrm{o}}\right.$, and Bray $\mathrm{P}$ as $\mathrm{kg}$ $\mathrm{ha}^{-1}$ ), soil C:N (molar), soil $\mathrm{N}: \mathrm{P}_{\mathrm{t}}$ (molar), foliar $\mathrm{N}(\%)$, foliar $\mathrm{P}(\%)$, and foliar N:P ratio (molar) were evaluated by linear regression using $\operatorname{lm}()$ function in R 3.4.1 [47]. We used all the exoenzymatic data in the analysis, regardless of whether the fungal partner was identified molecularly, as we considered morphological classification sufficient to determine mycorrhization. Before regressions were conducted, exoenzymatic activities were averaged by plot and then log-transformed in order to meet the normality criteria for linear regressions. Regression results for $\mathrm{P}_{\mathrm{i}}$ and Bray $\mathrm{P}$ were virtually identical so for brevity only $\mathrm{P}_{\mathrm{i}}$ outputs are presented here. A nonmetric multidimensional (NMDS) ordination of community composition between the three soil types, based on species incidence (Bray-Curtis dissimilarity), was undertaken with metaMDS() function and function ggplot2() [47].

\section{Results}

\section{Soil P status}

Upland Brunisols were well-endowed with readily available $\mathrm{P}$, as indicated by Bray $\mathrm{P}$ concentrations $\sim 25$ times greater (average 83 [SE 14] $\mathrm{mg} \mathrm{kg}^{-1}$ in mineral soil) than Podzols (average 3.2 [SE 0.6] mg kg${ }^{-1}$; Table 1). A similar contrast was found with inorganic $\mathrm{P}\left(\mathrm{P}_{\mathrm{i}}\right)$ concentrations, which averaged 760 [SE 101] $\mathrm{mg} \mathrm{kg}^{-1}$ in mineral soil for Brunisols and only 98 [SE 23] mg kg${ }^{-1}$ across Podzol plots. Organic $\mathrm{P}$ concentrations $\left(\mathrm{P}_{\mathrm{o}}\right)$, by contrast, were generally highest across lowland Podzols, especially in mineral soils and forest floors (Table 1). Data on the P content $\left(\mathrm{kg} \mathrm{ha}^{-1}\right)$ of the upper profiles of these soils were reported previously, along with foliar $\mathrm{N} \%$ and $\mathrm{P} \%$ [7].
In addition to differences in total $\mathrm{P}_{\mathrm{o}}$, NMR spectra revealed considerable differences in the chemical make-up of the organic P among soil types (Supplementary Fig. 1). Podzols had approximately twofold higher phosphodiester to orthophosphate ratios when compared to Brunisols, while phosphomonoester ratios were lowest in Upland Podzols and highest in Lowland Podzols (Table 2). Phosphonates were reasonably abundant in Lowland Podzols but were not detected in Brunisols (Table 2).

\section{Exoenzyme activity in relation to soil nutrient status}

Contrary to our hypothesis, none of the six exoenzyme activities measured on EM root-tip surfaces was related to soil $\mathrm{P}_{\mathrm{o}}$ content $\left(\mathrm{kg} \mathrm{ha}^{-1}\right.$ of the upper profile; Table 3). However, APD activity had a highly significant $(p=0.002$, adj. $R^{2}=0.59$ ), negative association with $\mathrm{P}_{\mathrm{i}}$ content (Fig. 1a), along with a similar but more marginal decline in APM activity with increasing $P_{i}$ (Table 3). The relationship of APD activity to soil $P_{i}$ was logarithmic, with a marked increase at $\mathrm{P}_{\mathrm{i}}$ contents $<150 \mathrm{~kg} \mathrm{ha}^{-1}$ (equivalent to $<5 \mathrm{~kg} \mathrm{ha}^{-1}$ Bray $\mathrm{P}$ ), for a fourfold increase $\left(0.03-0.12 \mu \mathrm{mol} \mathrm{mm} \mathrm{mm}^{-1}\right)$ in activity along the gradient from Brunisols to Podzols (Fig. 1a). The corresponding increase in APM activity was $\sim 2.5$-fold $\left(0.15-0.35 \mu \mathrm{mol} \mathrm{mm} \mathrm{min}^{-1}\right)$, although the concentrations of APM were 3-4x greater than APD overall. There were no significant changes in exoenzyme activity with soil $\mathrm{N}$ availability (as soil C:N ratio) over the podzolization gradient, but APD and $\beta-G U$ showed a positive trend with soil $\mathrm{N}: \mathrm{P}_{\mathrm{t}}$ (Table 3 and Fig. $1 \mathrm{~b}$ ).

While exoenzyme activity displayed no significant relationships with total soil $\mathrm{P}_{\mathrm{o}}$ content, specific components of the organic P identified by NMR appeared to be important. Specifically, we noted a strong, positive relationship $(p=$ 0.002 , adj. $R^{2}=0.90$ ) between APD activity and the ratio of phosphodiesters to orthophosphate across the subset of sites analyzed (Fig. 1c). The relationship between APM activity 
Table 2 Integration values for all NMR peaks when orthophosphate was set to 1.00 .

\begin{tabular}{lllllllll}
\hline Soil type & Plot & Monoesters & Diesters & Pyro-phosphate & Poly-phosphate & Phosphonates & P $_{\text {total }}^{\text {NMR }}$ & Orthophosphate/total \\
\hline Brunisol & Sooke & 0.82 & 0.19 & 0.16 & 0.15 & ND & 2.32 & 0.43 \\
Brunisol & Niagara & 1.03 & 0.28 & 0.17 & 0.22 & ND & 2.70 & 0.37 \\
Upland Podzol & Fairy Lake & 0.61 & 0.42 & 0.16 & 0.24 & 0.07 & 2.50 & 0.40 \\
Upland Podzol & WC 1000 & 0.65 & 0.48 & 0.14 & 0.23 & 0.08 & 2.58 & 0.39 \\
Lowland Podzol & Branch 136 & 1.30 & 0.48 & 0.18 & 0.19 & 0.32 & 3.47 & 0.29 \\
Lowland Podzol & Branch 247-63 & 1.45 & 0.51 & 0.18 & 0.20 & 0.28 & 3.62 & 0.28 \\
\hline
\end{tabular}

The values are proportional to $\mathrm{P}$ concentration. $\mathrm{P}_{\text {total }}{ }^{\mathrm{NMR}}$ is the sum of all integration values except the internal standard. $N D$ not detected.

Table 3 Statistical significance of exoenzyme activities $\left(\mu \mathrm{mol} \mathrm{mm} \mathrm{min}^{-1}\right)$ in linear regressions with soil inorganic $\mathrm{P}\left(\mathrm{P}_{\mathrm{i}}\right)$ and organic $\mathrm{P}\left(\mathrm{P}_{\mathrm{o}}\right)$ content $\left(\mathrm{kg} \mathrm{ha}^{-1}\right)$, along with soil $\mathrm{C}: \mathrm{N}$ and $\mathrm{N}: \mathrm{P}_{\mathrm{t}}$ ratios (enzymes values $\log$-transformed, $p$ values $<0.05$ in bold).

\begin{tabular}{|c|c|c|c|c|c|c|c|c|c|c|c|c|}
\hline & \multicolumn{3}{|l|}{ Soil $P_{i}$} & \multicolumn{3}{|l|}{ Soil $P_{o}$} & \multicolumn{3}{|c|}{ Soil C:N } & \multicolumn{3}{|c|}{ Soil $\mathrm{N}: \mathrm{P}_{\mathrm{t}}$} \\
\hline & $p$ value & Slope & $R^{2}$ & $p$ value & Slope & $R^{2}$ & $p$ value & Slope & $R^{2}$ & $p$ value & Slope & $R^{2}$ \\
\hline APM & 0.068 & $-4.0 \mathrm{e}^{-4}$ & 0.22 & 0.477 & - & - & 0.142 & - & - & 0.123 & - & - \\
\hline APD & 0.002 & $-1.4 \mathrm{e}^{-3}$ & 0.59 & 0.165 & - & - & 0.331 & - & - & 0.017 & $3.8 \mathrm{e}^{-2}$ & 0.40 \\
\hline LAC & 0.118 & - & - & 0.355 & - & - & 0.100 & - & - & 0.130 & - & - \\
\hline NAG & 0.472 & - & - & 0.502 & - & - & 0.483 & - & - & 0.264 & - & - \\
\hline GU & 0.101 & - & - & 0.240 & - & - & 0.544 & - & - & 0.062 & $1.4 \mathrm{e}^{-2}$ & 0.24 \\
\hline X & 0.186 & - & - & 0.195 & - & - & 0.379 & - & - & 0.102 & - & - \\
\hline
\end{tabular}

$A P M$ acid phosphomonoesterase, $A P D$ acid phosphodiesterase, $L A C$ laccase, $N A G \mathrm{~N}$-acetyl glucosaminidase, $G U \beta$-glucosidase, $X$ xylosidase. and the relative concentration of phosphodiesters was also significant but weaker (data not shown; $p=0.048$; adj. $\left.R^{2}=0.58\right)$.

\section{Exoenzyme activity in relation to foliar nutrient concentrations and stoichiometry}

Foliar attributes, particularly $\mathrm{P} \%$ and $\mathrm{N}: \mathrm{P}$ ratio, had stronger relationships than the soil variables with exoenzyme activities (Table 4). We found clear declines in four of the six exoenzyme activities with increasing foliar $\mathrm{P}$, but only one marginal gain (LAC) in relation to foliar $\mathrm{N}$ (Table 4 and Fig. 2). The extent of $\mathrm{P}$ deficiencies in relation to $\mathrm{N}$, as measured by foliar $\mathrm{N}: \mathrm{P}$, was a more precise predictor than $\mathrm{P} \%$ of exoenzyme activities, with significant positive correlations for all six exoenzymes. The relationships for foliar $\mathrm{N}: \mathrm{P}$ were particularly robust (adj. $R^{2}>0.5$ ) for APD, APM, and LAC activity (Table 4 and Fig. 2b, f). When aligned with increasing foliar $\mathrm{N}: \mathrm{P}$, the net gains in LAC, $\beta-\mathrm{GU}$, and $\mathrm{X}$ exoenzyme activity ranged from two- to fivefold (Fig. 2d, f).

\section{Exoenzyme activity in relation to EM fungal species}

Root tips examined from the 12 plots were virtually $100 \%$ EM. Of 157 EM fungal clusters sampled, 130 were successfully sequenced $(83 \%)$. Overall, we identified 31 EM fungal species across the Brunisol plots, 36 species in
Upland Podzols, and 35 species on Lowland Podzols (Supplementary Table 1). The EM fungal communities of the Podzol and Brunisol soil types clustered separately in the NMDS ordination, with some overlap between Upland and Lowland Podzol plots (Fig. 3).

A small subset of species, or multiple species from diverse genera (e.g., Cortinarius), was sampled frequently enough $(>3)$ to illustrate some contrasts in exoenzyme activity among ectomycorrhizae formed by different fungal taxa (Fig. 4). The abundant ectomycorrhizae found only on Podzol sites, such as those formed by Lactarius substriatus, L. subviscidus, and Russula brevipes var. acrior had notably high expression of all three key exoenzymes (APM, APD, LAC). By contrast, Russula xerampelina, Cenococcum geophilum, and Piloderma olivaceum mycorrhizae, which were found almost exclusively on Brunisols, had much lower APD and LAC activity, while some genera, such as Cortinarius, were found across much of the edaphic gradient but featured little capacity for P-acquiring exoenzymes (Fig. 4).

\section{Discussion}

The diversity of nutrient acquisition traits among EM fungal species has been posited to explain niche breadths of EM plants [48]. One challenging niche for the growth and establishment of trees is P-deficient soil, which can occur as 

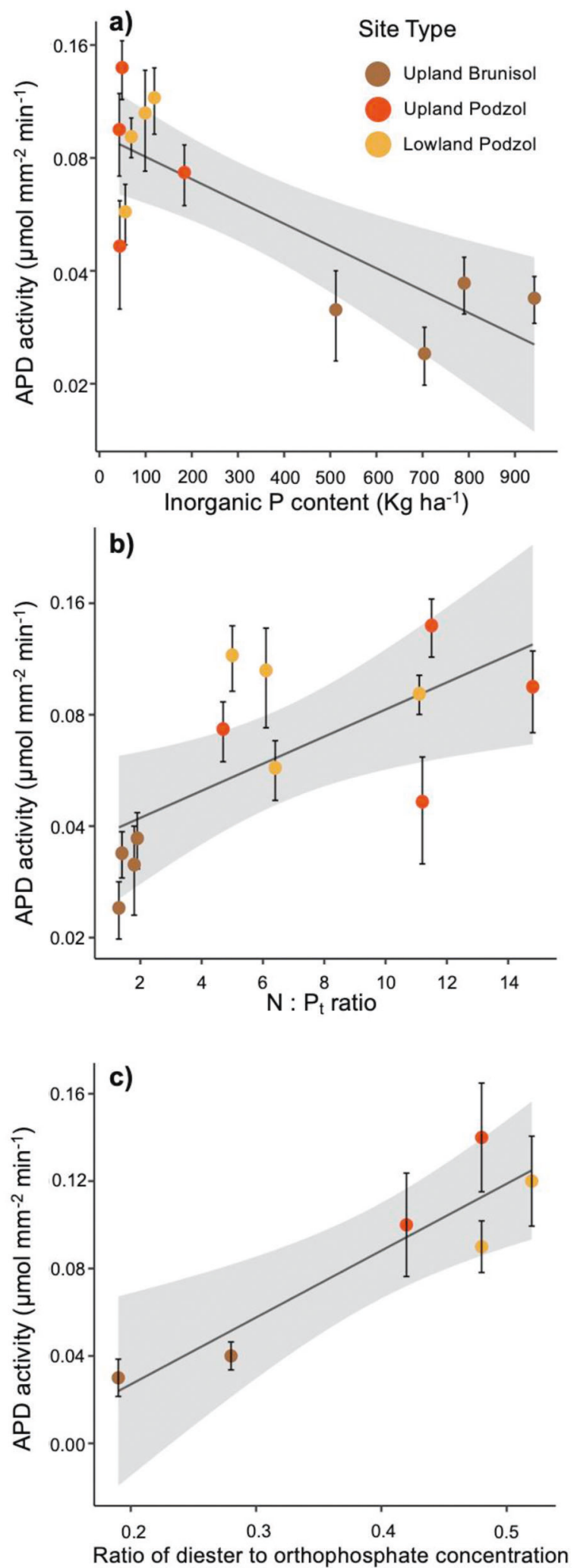

Fig. 1 Linear regressions between average acid phosphodiesterase (APD) activity (log-transformed) and soil properties. APD activity in relation to a soil inorganic $\mathrm{P}$ content, $\mathbf{b}$ soil $\mathrm{N}: \mathrm{Pt}$ molar ratio $(N=$ $12)$, and $\mathbf{c}$ ratio of diester to orthophosphate concentration $(N=6)$. (SE of plots as error bars, SE of regressions as shaded area). a result of natural weathering as well as in landscapes where $\mathrm{P}$ imbalances have been induced by $\mathrm{N}$ deposition or climate change [6, 31]. In a naturally occurring gradient of $\mathrm{P}$ availability across southern Vancouver Island, we found evidence that EM fungal communities use different $\mathrm{P}$ acquisition strategies depending on soil type, and that those strategies are tightly coupled with host foliar nutrition and stoichiometry. Specifically, EM fungal communities on Douglas-fir roots in P-deficient podzolized soils had much higher (two- to fivefold) activities of direct (APM, APD) and indirect (LAC, $\mathrm{X}, \beta-\mathrm{GU}$ ) P-acquiring exoenzymes than EM fungal communities in P-sufficient Brunisols. The large increases in exoenzyme activity by site-specific EM fungal communities and their associated microbiome [49] emphasizes the strong plant-soil feedbacks operating in these coastal ecosystems.

Even though phosphatase activities were highest in Podzols, with their high $\mathrm{P}_{\mathrm{O}}: \mathrm{P}_{\mathrm{i}}$ ratios, activities were more closely related to measures of inorganic than organic $\mathrm{P}$ in soil. This is consistent with other studies on ectomycorrhizas, where a negative relationship between inorganic $\mathrm{P}$ and EM mantle surface APM has been found ([50,51], but see ref. [52]), indicating the likelihood of product (i.e., orthophosphate) inhibition [51]. Furthermore, in studies where $\mathrm{P}_{\mathrm{o}}$ has been applied to pure fungal cultures, soils, or EM plants [53-56], only one study found any relationship between $\mathrm{P}_{\mathrm{o}}$ and APM activity, in that case a negative one [57]. The lack of any relationship between phosphatases and total soil $\mathrm{P}_{\mathrm{o}}$ in our study and others may be because some forms of the organic $\mathrm{P}$ do not act as a substrate for these exoenzymes. For example, phosphonates, which were relatively abundant in the lowland Podzols, are generally considered very resistant to microbial degradation [58]. In addition, a large proportion of the $\mathrm{P}_{\mathrm{o}}$ was likely phytate [59], which, although it would have been grouped with monoesters in our NMR analysis, may not be used effectively by EM fungi [60]. When we quantified the relative amounts of diesters using ${ }^{31} \mathrm{P}$ NMR, we were able to show a strong positive correlation with both APD and APM, suggesting that these exoenzymes were being produced in response to the increase of their substrates within the soil organic matter at Podzol sites. Phosphomonoesters are one of the products of phosphodiesterase activity.

Of the two types of phosphatase activity measured, APD appeared to be especially important in the response of ectomycorrhizas to low $\mathrm{P}_{\mathrm{i}}$. While the production of APD has been described as an important $\mathrm{P}$-acquisition strategy of mycorrhizal fungi [10, 61], and other soil microbes [62, 63], it is often not included in EM enzymatic studies (but see refs. [64, 65]). Like APM, soil APD is integral to P cycling [15]. Phosphodiesters are considered to be important for the replenishment of $\mathrm{P}_{\mathrm{i}}$ in soils because their phosphate groups are shielded from ionic interactions, making them less likely 
Table 4 Statistical significance of exoenzyme activities $\left(\mu \mathrm{mol} \mathrm{mm} \mathrm{min}^{-1}\right)$ in linear regressions with foliar nitrogen, phosphorus, and $\mathrm{N}: \mathrm{P}$ ratio (enzyme values log-transformed, $p$ values $<0.05$ in bold).

\begin{tabular}{|c|c|c|c|c|c|c|c|c|c|}
\hline & \multicolumn{3}{|c|}{ Foliar N (\%) } & \multicolumn{3}{|c|}{ Foliar P (\%) } & \multicolumn{3}{|c|}{ Foliar N:P } \\
\hline & $p$ value & Slope & $R^{2}$ & $p$ value & Slope & $R^{2}$ & $p$ value & Slope & $R^{2}$ \\
\hline APM & 0.144 & - & - & 0.010 & -1.23 & 0.45 & 0.002 & 0.010 & 0.62 \\
\hline APD & 0.160 & - & - & 0.002 & -0.79 & 0.58 & $<0.001$ & 0.007 & 0.73 \\
\hline LAC & 0.078 & 0.28 & 0.21 & 0.021 & -1.01 & 0.37 & 0.004 & 0.009 & 0.54 \\
\hline NAG & 0.158 & - & - & 0.172 & - & - & 0.043 & 0.006 & 0.28 \\
\hline GU & 0.345 & - & - & 0.027 & -0.42 & 0.34 & 0.021 & 0.003 & 0.37 \\
\hline $\mathrm{X}$ & 0.101 & - & - & 0.055 & -0.15 & 0.25 & 0.013 & 0.001 & 0.42 \\
\hline
\end{tabular}

Enzyme abbreviations as in Table 3.
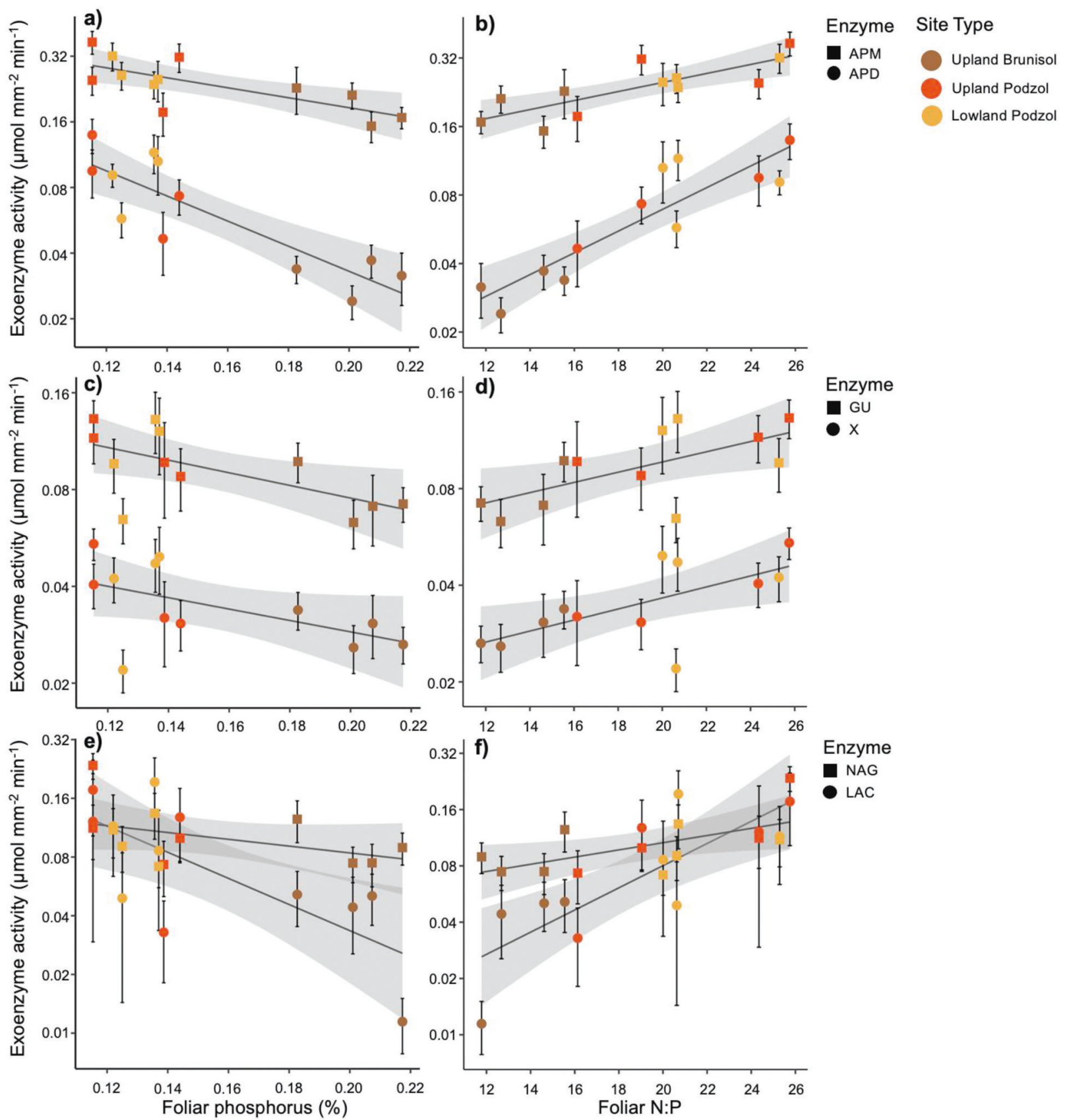

Fig. 2 Linear regressions of exoenzyme activity (log-transformed) with foliar attributes. First column depicts foliar $\mathrm{P} \%$ and second column foliar N:P (molar ratio) for $\mathbf{a}, \mathbf{b}$ acid phosphomonoesterase (APM) and phosphodiesterase (APD); c, d xylosidase (X) and b-glucosidase (GU); and e, f laccace (LAC) and $\mathrm{N}$ acetylglucosaminidase (NAG). $(N=12, \mathrm{SE}$ of plots as error bars, SE of regressions as shaded area). 
to be adsorbed to soil particles and more accessible to enzymatic cleavage $[66,67]$. The activity of APD can be the rate-limiting step in $\mathrm{P}_{\mathrm{o}}$ turnover of some soils [68] because, unlike the $\mathrm{P}$ in monoesters, the release of $\mathrm{P}$ from soil phosphodiesters appears to be limited by enzyme availability [16]. In our study, the net increase in APD activity was twice that of APM across the edaphic gradient, emphasizing the focused allocation of resources to this exoenzyme.

The strong relationship we uncovered between EM exoenzyme activity and foliar N:P ratio was a key finding of this study and illustrates succinctly how the mycorrhizas

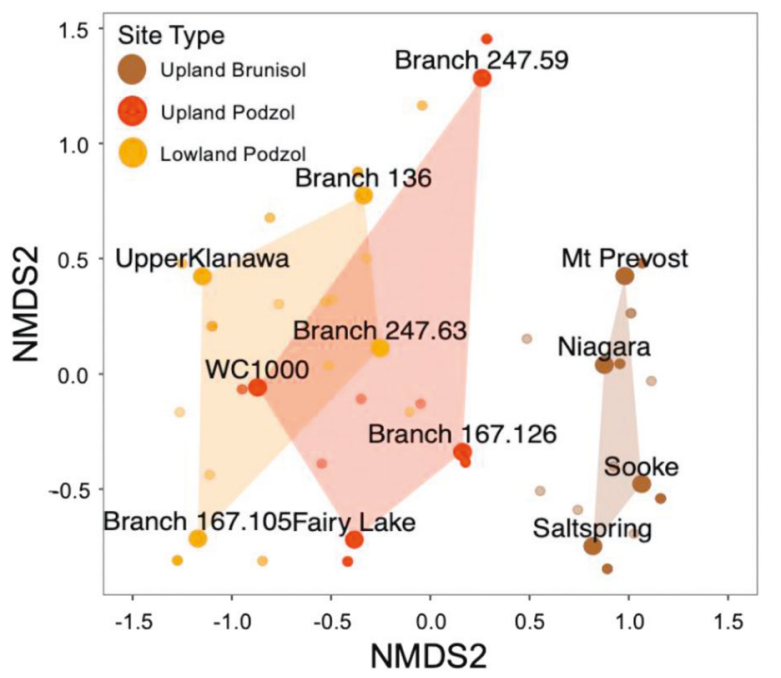

Fig. 3 Nonmetric multidimensional scaling ordination of EM communities (species incidence) between the three soil types. Ordination of EM communities from 12 plots, individual EM species represented by smaller points colored according to predominant soil type. likely participated in an optimal allocation strategy [31]. According to this model, plants and mycorrhizal fungi allocate biomass and energy to strategies that will acquire the more limiting nutrient(s), because organisms function optimally when stoichiometry is maintained. Consequently, at $\mathrm{N}: \mathrm{P}$ foliar ratios below a threshold (generally 14-16) [69], resources would be expected to be focused on $\mathrm{N}$ acquisition, but above this threshold the limitations from $\mathrm{P}$ would equal and then surpass that of $\mathrm{N}$. In this way the energy devoted by the EM fungi to exoenzyme allocation was more precisely governed by $\mathrm{P}$ deficiency in relation to $\mathrm{N}$ constraints, rather than $\mathrm{P}$ availability alone. The $\mathrm{N}: \mathrm{P}$ ratios of EM fruiting bodies from these plots were nearly identical to P. menzesii foliar N:P [7], so the exoenzyme allocation strategy documented here reflects the stoichiometry of both the fungal symbiont and the tree, as would be expected if the host/symbiont relationship is viewed as a "holobiont" [70]. Foliar N:P, it should be noted, is a more expedient measure of resource availability than soil pools, especially $\mathrm{P}_{\mathrm{o}}$, but can also be a somewhat dynamic property that is affected by, for example, stand development stage [71] or interannual climatic variation [72].

The prominent EM fungal species producing the highest quantities of P-acquiring exoenzymes (e.g., Lactarius substriatus, Russula brevipes var. acrior, Lactarius subviscidus) were found only on the strongly podzolized soils of the west coast of Vancouver Island, both in the sampling of this study and in previous, extensive EM fungal surveys of eastern Vancouver Island [73]. The wholescale species turnover within EM fungal communities likely selected for species that are adapted to exploiting $P_{0}$, as indicated by enzymatic traits, and thereby able to outcompete other EM and saprotrophic fungi $[29,74]$. Because of the dependence of $P$. menzesii on
Fig. 4 Average exoenzyme activity of acid

phosphomonoesterase, acid phosphodiesterase, and laccase for select fungal taxa. Number of observations per fungal taxa in brackets, SE as bars.

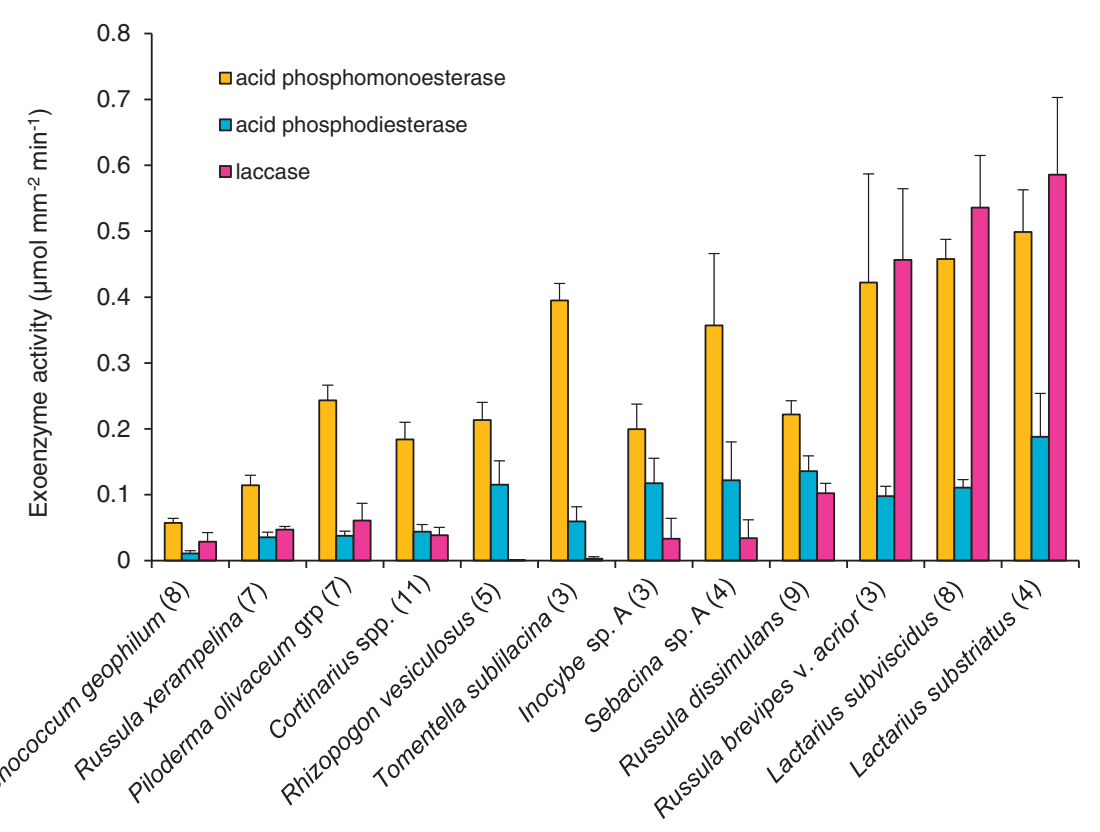


ectomycorrhizas for acquiring soil nutrients, these traits would also maximize fitness of the host in response to $\mathrm{P}$ scarcity, with better adapted EM fungi possibly favored by the host tree through the targeted provision of carbon [75], or by downregulation of plant defenses during root colonization [76]. Through competition with other fungi and/or support by the tree, assembly of the Podzol EM fungal communities could have involved selection of either fungal species [77] or individual fungi within the population with appropriate $\mathrm{P}$ acquisition traits, or acclimation of existing fungi to the low $\mathrm{P}_{\mathrm{i}}$ and high $\mathrm{P}_{\mathrm{o}}$ through upregulation of phosphatase genes. Given the high $\beta$ diversity across this landscape, it appears less likely that capacity for physiological plasticity by fungal individuals or intraspecific variations were drivers of EM fungal community assembly here [27]. Some controlled, manipulative studies (e.g., reciprocal seedling transplants across soil types; [78]) could be used to test these capacities more thoroughly.

EM fungi are known to structure bacterial communities on their mantle surfaces and in soil [79]. The contribution of mantle-associated bacteria and archaea to exoenzyme activities measured in our study is not known, but incorporating antibiotics into assays have indicated a minor effect [80]. In addition, some of the variation in exoenzyme activities could reflect in part the morphology of the mantle, particularly for medium- and long-distance exploration types if extramatrical hyphae were lost during root preparation [44]. However, this potential bias should not have affected the average EM community response in exoenzyme activity since we found a mix of contact, short- and medium-distance mantles across all study plots. Furthermore, the considerable differences in exoenzyme activity among taxa within an exploration type, such as the contact mantle of Russula xerampelina and Lactarius substriatus, are consistent with a dominant effect of fungal species on these key traits [20-22, 41, 81].

\section{Conclusions}

A podzolization gradient across a short transect of temperate coastal forests provided an ideal field test for differences in P-acquisition strategies among EM fungal communities of $P$. menzesii. Our results establish a significant role for APD in the acclimation of EM fungi to low $P_{i}$ soils. The close link in exoenzyme activity with host stoichiometry highlighted the importance of assessing $\mathrm{P}$ deficiency in relation to $\mathrm{N}$ constraints, rather than $\mathrm{P}$ alone, as would be consistent with an optimal allocation strategy. The EM fungal species with the highest expression of key exoenzymes were found only on Podzols and underscore how resource constraints, such as sharp declines in $\mathrm{P}_{\mathrm{i}}$ with soil podzolization, likely drive species turnover and the assembly of distinct, well-adapted EM fungal communities. Large increases in many key exoenzymes by site-specific EM fungi illustrate how a diverse symbiotic community greatly enhances the ability of a single tree host to accommodate the severe edaphic constraints inherent to these wet coastal landscapes.

\section{Data availability}

Available at Dryad (https://doi.org/10.5061/dryad. tht76hdxq). Molecular sequences accessioned with UNITE (UDB0779903-UDB0779958).

Acknowledgements We thank Louise deMontigny and Michael Stoehr (B.C. Ministry of Forests, Victoria) for supporting studies on these long-term experimental plots. Also thanks to Joel Ussery (Capital Regional District, Victoria) for access to the watersheds on eastern Vancouver Island. Ariana Sholinder (University of Victoria) provided valuable support in root sampling and exoenzyme assays and Barbara Hawkins (University of Victoria) assisted with logistical support. Grace Ross and Tyler Dyer (Pacific Forestry Centre) contributed to the molecular sequencing. We thank John Klironomos (University of British Columbia) for helpful discussions. Funding for this project was provided by the NSERC Discovery Grant Program to MDJ (RGPIN-2018003927).

Author contributions JAM, JMK, and MDJ conceived study; JAM and JMK sampled soils and roots; JAM, JMK, IZ, DD, FM, and PS carried out exoenzyme assays, molecular sequencing, and NMR analysis; JAM, JMK, and MDJ analyzed data; and JAM led the writing with substantial contributions from JMK and MDJ.

\section{Compliance with ethical standards}

Conflict of interest The authors declare that they have no conflict of interest.

Publisher's note Springer Nature remains neutral with regard to jurisdictional claims in published maps and institutional affiliations.

Open Access This article is licensed under a Creative Commons Attribution 4.0 International License, which permits use, sharing, adaptation, distribution and reproduction in any medium or format, as long as you give appropriate credit to the original author(s) and the source, provide a link to the Creative Commons license, and indicate if changes were made. The images or other third party material in this article are included in the article's Creative Commons license, unless indicated otherwise in a credit line to the material. If material is not included in the article's Creative Commons license and your intended use is not permitted by statutory regulation or exceeds the permitted use, you will need to obtain permission directly from the copyright holder. To view a copy of this license, visit http://creativecommons. org/licenses/by/4.0/.

\section{References}

1. Vitousek PM, Porder S, Houlton BZ, Oliver A, Vitousek PM, Porder S, et al. Terrestrial phosphorus limitation: mechanisms, implications, and nitrogen-phosphorus interactions. Ecol Appl. 2010;20:5-15. 
2. Lundstrom US, Van Breemen N, Bain D. The podzolization process. A review. Geoderma. 2000;94:91-107.

3. Crowley KF, Mcneil BE, Lovett GM, Canham CD, Driscoll CT, Rustad LE, et al. Do nutrient limitation patterns shift from nitrogen toward phosphorus with increasing nitrogen deposition across the northeastern United States? Ecosystems. 2012;15:940-57.

4. Jonard M, Fürst A, Verstraeten A, Thimonier A, Timmermann V, Potočić N, et al. Tree mineral nutrition is deteriorating in Europe. Glob Change Biol. 2015;21:418-30.

5. Hayward J, Horton TR, Nu MA. Ectomycorrhizal fungal communities coinvading with Pinaceae host plants in Argentina: Gringos bajo el bosque. N Phytol. 2015;208:497-506.

6. Köhler J, Yang N, Pena R, Raghavan V, Polle A, Meier IC. Ectomycorrhizal fungal diversity increases phosphorus uptake efficiency of European beech. N Phytol. 2018;220:1200-10.

7. Kranabetter JM, Harman-Denhoed R, Hawkins BJ. Saprotrophic and ectomycorrhizal fungal sporocarp stoichiometry (C: N: P) across temperate rainforests as evidence of shared nutrient constraints among symbionts. N Phytol. 2019;221:482-92.

8. Ning C, Xiang W, Mueller GM. Differences in ectomycorrhizal community assembly between native and exotic pines are reflected in their enzymatic functional capacities. Plant Soil. 2019;446:179-93.

9. Courty PE, Buée M, Diedhiou AG, Frey-Klett P, Le Tacon F, Rineau F, et al. The role of ectomycorrhizal communities in forest ecosystem processes: new perspectives and emerging concepts. Soil Biol Biochem. 2010;42:679-98.

10. Cairney JWG. Ectomycorrhizal fungi: the symbiotic route to the root for phosphorus in forest soils. Plant Soil. 2011;344:51-71.

11. Hodge A. Accessibility of inorganic and organic nutrients for mycorrhizas. In: Johnson NC, Gehring CA, Jansa J, editors. Mycorrhizal mediation of soil: fertility, structure, and carbon storage. Amsterdam: Elsevier; 2017. p. 129-48.

12. Plassard C, Louche J, Ali MA, Duchemin M, Legname E, Cloutier-Hurteau B. Diversity in phosphorus mobilisation and uptake in ectomycorrhizal fungi. Ann Sci. 2011;68:33-43.

13. Becquer A, Trap J, Irshad U, Ali MA, Claude P. From soil to plant, the journey of $\mathrm{P}$ through trophic relationships and ectomycorrhizal association. Front Plant Sci. 2014;5:1-7.

14. Tunlid A, Floudas D, Koide RT, Rineau F. Soil organic matter decomposition mechanisms in ectomycorrhizal fungi. In: Martin FM, editor. Molecular mycorrhizal symbiosis. 1st ed. Hoboken, New Jersey, USA: John Wiley \& Sons, Inc; 2017. p. 257-75.

15. Nannipieri P, Giagnoni L, Landi L, Renella G. Role of phosphatase enzymes in soil. In: Bunemann et al., editors. Phosphorus in action. Berlin, Heidelberg: Springer Verlag; 2011. p. 215-43.

16. Jarosch KA, Kandeler E, Frossard E, Bünemann EK. Is the enzymatic hydrolysis of soil organic phosphorus compounds limited by enzyme or substrate availability? Soil Biol Biochem. 2019;139:1-11.

17. Bending GD, Read DJ. The structure and function of the vegetative mycelium of ectomycorrhizal plants: VI. Activities of nutrient mobilizing enzymes in birch litter colonized by Paxillus involutus (Fr.) Fr. N Phytol. 1995;130:411-7.

18. Liu X, Feng F, He X, Song F. The effect of ectomycorrhizal fungi on litter decomposition and phosphorus availability to Pinus koraiensis. Int J Agric Biol. 2017;19:1019-24.

19. Read DJ, Perez-Moreno J. Mycorrhizas and nutrient cycling in ecosystems - a journey towards relevance? N Phytol. 2003;157:475-92.

20. Jones MD, Twieg BD, Ward V, Barker JS, Durall DM, Simard SW. Functional complementarity of Douglas-fir ectomycorrhizas for extracellular enzyme activity after wildfire or clearcut logging. Funct Ecol. 2010;24:1139-51.

21. Alvarez M, Huygens D, Díaz LM, Villanueva CA, Heyser W, Boeckx P. The spatial distribution of acid phosphatase activity in ectomycorrhizal tissues depends on soil fertility and morphotype, and relates to host plant phosphorus uptake. Plant, Cell Environ. 2012;35:126-35.

22. Walker JKM, Cohen H, Higgins LM, Kennedy PG. Testing the link between community structure and function for ectomycorrhizal fungi involved in a global tripartite symbiosis. N Phytol. 2014;202:287-96.

23. Zavišić A, Nassal P, Yang N, Heuck C, Spohn M, Marhan S, et al. Phosphorus availabilities in beech (Fagus sylvatica L.) forests impose habitat filtering on ectomycorrhizal communities and impact tree nutrition. Soil Biol Biochem. 2016;98:127-37.

24. Patterson A, Flores-renter L, Whipple A, Whitham T, Gehring C. Common garden experiments disentangle plant genetic and environmental contributions to ectomycorrhizal fungal community structure. N Phytol. 2019;221:493-502.

25. Koide RT, Fernandez C, Petprakob K. General principles in the community ecology of ectomycorrhizal fungi. Ann Sci. 2011;68:45-55.

26. Bahram M, Kohout P, Anslan S, Harend H, Abarenkov K. Stochastic distribution of small soil eukaryotes resulting from high dispersal and drift in a local environment. ISME J. 2016;10:885-96.

27. Courty P-E, Munoz F, Selosse M-A, Duchemin M, Criquet S, Ziarelli $\mathrm{F}$, et al. Into the functional ecology of ectomycorrhizal communities: environmental filtering of enzymatic activities. J Ecol. 2016;104:1585-98.

28. Walker JKM, Ward V, Jones MD. Ectomycorrhizal fungal exoenzyme activity differs on spruce seedlings planted in forests versus clearcuts. Trees - Struct Funct. 2016;30:497-508.

29. Kyaschenko J, Clemmensen KE, Karltun E, Lindahl BD. Belowground organic matter accumulation along a boreal forest fertility gradient relates to guild interaction within fungal communities. Ecol Lett. 2017;20:1546-55.

30. Kranabetter JM, Hawkins BJ, Jones MD, Robbins S, Dyer T, Li T. Species turnover (beta-diversity) in ectomycorrhizal fungi linked to NH4 (+) uptake capacity. Mol Ecol. 2015;24:5992-6005.

31. Johnson NC, Wilson GWT, Bowker MA, Wilson JA, Miller RM. Resource limitation is a driver of local adaptation in mycorrhizal symbioses. Proc Natl Acad Sci. 2010;107:2093-8.

32. Pickles BJ, Twieg BD, Neill GAO, Mohn WW, Simard SW. Local adaptation in migrated interior Douglas-fir seedlings is mediated by ectomycorrhizas and other soil factors. N Phytol. 2015;207:858-71.

33. Kranabetter JM, Stoehr M, O’Neill GA. Ectomycorrhizal fungal maladaptation and growth reductions associated with assisted migration of Douglas-fir. N Phytol. 2015;206:1135-44.

34. Mooshammer M, Wanek W, Zechmeister-boltenstern S, Richter A. Stoichiometric imbalances between terrestrial decomposer communities and their resources: mechanisms and implications of microbial adaptations to their resources. Front Microbiol. 2014;5:1-11.

35. Treseder KK, Vitousek PM. Effects of soil nutrient availablity on investment in acquisition of $\mathrm{N}$ and $\mathrm{P}$ in Hawaiian rain forests. Ecology. 2001;82:946-54.

36. Revillini D, Gehring CA, Johnson NC. The role of locally adapted mycorrhizas and rhizobacteria in plant-soil feedback systems. Funct Ecol. 2016;30:1086-98.

37. Marklein AR, Houlton BZ. Nitrogen inputs accelerate phosphorus cycling rates across a wide variety of terrestrial ecosystems. N Phytol. 2011;193:696-704.

38. Zechmeister-Boltenstern S, Keiblinger KM, Mooshammer M, Peñuelas J, Richter A, Sardans J, et al. The application of ecological stoichiometry to plant-microbial-soil organic matter transformations. Ecol Monogr. 2015;85:133-55.

39. Carter MR, Gregorich E. Soil sampling and methods of analysis. 2nd ed. Boca Raton, Florida: CRC Press; 2008. p. 823.

40. Green RN, Trowbridge RL, Klinka K. Towards a taxonomic classification of humus forms. Sci Monogr. 1993;29:1-48. 
41. Cade-Menun BJ. Improved peak identification in 31 P-NMR spectra of environmental samples with a standardized method and peak library. Geoderma. 2015;257-258:102-14.

42. Pritsch K, Courty PE, Churin JL, Cloutier-Hurteau B, Ali MA, Damon $\mathrm{C}$, et al. Optimized assay and storage conditions for enzyme activity profiling of ectomycorrhizae. Mycorrhiza. 2011;21:589-600.

43. Eivazi F, Tabatabai M. Phosphatases in soils. Soil Biol Biochem. 1977;9:167-72.

44. Pritsch K, Garbaye J. Enzyme secretion by ECM fungi and exploitation of mineral nutrients from soil organic matter. Ann Sci. 2011;68:25-32.

45. Courty PE, Pritsch K, Schloter M, Hartmann A, Garbaye J. Activity profiling of ectomycorrhiza communities in two forest soils using multiple enzymatic tests. N Phytol. 2005;167:309-19.

46. Kõljalg U, Nilsson RH, Abarenkov K, Tedersoo L, Taylor AFS, Bahram M, et al. Towards a unified paradigm for sequence-based identification of fungi. Mol Ecol. 2013;22:5271-7.

47. Team RC. R: a language and environment for statistical computing. Vienna, Austria: R Foundation for Statistical Computing; 2017.

48. Gerz M, Guillermo Bueno C, Ozinga WA, Zobel M, Moora M. Niche differentiation and expansion of plant species are associated with mycorrhizal symbiosis. J Ecol. 2018;106:254-64.

49. Carrara JE, Walter CA, William JSH, Brzostek ER, Averill TPC. Interactions among plants, bacteria, and fungi reduce extracellular enzyme activities under long-term $\mathrm{N}$ fertilization. Glob Change Biol. 2018;24:2721-34.

50. Bartlett EM, Lewis DH. Surface phosphatase activity of mycorrhizal roots of Beech. Soil Biol Biochem. 1973;5:249-57.

51. Allison SD, Vitousek PM. Responses of extracell enzymes to simple and complex nutrient inputs. Soil Biol Biochem. 2005;37:937-44

52. Alexander IJ, Hardy K. Surface phosphatase activity of Sitka spruce mycorrhizas from a serpentine site. Soil Biol Biochem. 1981;13:301-5.

53. Ali MA, Louche J, Legname E, Duchemin M, Plassard C. Pinus pinaster seedlings and their fungal symbionts show high plasticity in phosphorus acquisition in acidic soils. Tree Physiol. 2009;29:1587-97.

54. Antibus RK, Sinsabaugh RL, Linkins AE. Phosphatase activities and phosphorus uptake from inositol phosphate by ectomycorrhizal fungi. Can J Bot. 1992;70:794-801.

55. Tibbett M, Sanders FE, Cairney JWG. The effect of temperature and inorganic phosphorus supply on growth and acid phosphatase production in arctic and temperate strains of ectomycorrhizal Hebeloma spp. in axenic culture. Mycol Res. 1998;102:129-35.

56. van Aarle IM, Plassard C. Spatial distribution of phosphatase activity associated with ectomycorrhizal plants is related to soil type. Soil Biol Biochem. 2010;42:324-30.

57. Kroehler J, Linkins E. The effects of organic and inorganic phosphorus concentration on the acid phosphatase activity of ectomycorrhizal fungi. Can J Bot. 1987;66:750-6.

58. Horsman GP, Zechel DL. Phosphonate biochemistry. Chem Rev. 2017;117:5704-83.

59. Turner BL. Inositol phosphates in soil: amounts, forms and significance of the phosphorylated inositol stereoisomers. In: Turner BL, Richardson AE, Mullaney EJ, editors. Inositol phosphates: linking agriculture and the environment. Wallingford, UK: $\mathrm{CAB}$ International; 2007. p. 186-207.

60. Colpaert JV, Van Laere A, Van Tichelen KK, Van, Assche JA. The use of inositol hexaphosphate as a phosphorus as a phosphorus source by mycorrhizal and non-mycorrhizal Scots Pine (Pinus sylvestris). Funct Ecol. 1997;11:407-15.

61. Leake JR, Miles W. Phosphodiesters as mycorrhizal P sources I. Phosphodiesterase production and the utilization of DNA as a phosphorus source by the ericoid mycorrhizal fungus Hymenoseyphus ericae. N Phytol. 1996;132:435-43.

62. Lang F, Krüger J, Amelung W, Willbold S, Frossard E, Bünemann EK, et al. Soil phosphorus supply controls $\mathrm{P}$ nutrition strategies of beech forest ecosystems in Central Europe. Biogeochemistry. 2017;136:5-29.

63. Criquet S, Ferre E, Farnet AM, Le Petit J. Annual dynamics of phosphatase activities in an evergreen oak litter: Influence of biotic and abiotic factors. Soil Biol Biochem. 2004;36:1111-8.

64. Antibus RK, Bower D, Dighton J. Root surface phosphatase activities and uptake of 32P-labelled inositol phosphate in fieldcollected gray birch and red maple roots. Mycorrhiza. 1997:7:39-46.

65. Steidinger BS, Turner BL, Corrales A, Dalling JW. Variability in potential to exploit different soil organic phosphorus compounds among tropical montane tree species. Funct Ecol. 2015;29:121-30.

66. Tate KR, Newman RH. Phosphorus fractions of a climosequence of soils in New Zealand tussock grasslands. Soil Biol Biochem. 1981;191:191-6.

67. Stewart JWB, Tiessen H. Dynamics of soil organic phosphorus. Biogeochemistry. 1987;4:41-60.

68. Turner BL, Haygarth PM. Phosphatase activity in temperate pasture soils: potential regulation of labile organic phosphorus turnover by phosphodiesterase activity. Sci Total Environ. 2005;344:27-36.

69. Reich PB, Oleksyn J. Global patterns of plant leaf $\mathrm{N}$ and $\mathrm{P}$ in relation to temperature and latitude. PNAS. 2004;101:11001-6.

70. Vandenkoornhuyse P, Quaiser A, Duhamel M, Le Van A, Dufresne A. The importance of the microbiome of the plant holobiont. N Phytol. 2015;206:1196-206.

71. Zhang H, Wang J, Wang J, Guo Z, Geo G, Zeng D. Tree stoichiometry and nutrient resorption along a chronosequence of Metasequoia glyptostroboides forests in coastal China. Ecol Manag. 2018:430:445-50.

72. Duquesnay A, Dupouey JL, Clement A, Ulrich E, Tacon FLE. Spatial and temporal variability of foliar mineral concentration in beech (Fagus sylvatica) stands in northeastern France. Tree Physiol. 2000;20:13-22.

73. Kranabetter JM, Berch S, MacKinnon J, Ceska O, Dunn D, Ott P. Species-area curve and distance-decay relationships indicate habitat thresholds of ectomycorrhizal fungi in an old-growth Pseudotsuga menziesii landscape. Divers Distrib. 2018;24:755-64.

74. Zavisic A, Yang N, Marhan S, Kandeler E, Polle A. Forest soil phosphorus resources and fertilization affect ectomycorrhizal community composition, Beech $\mathrm{P}$ uptake efficiency, and photosynthesis. Front Plant Sci. 2018;9:1-13.

75. Bogar L, Peay KG, Kornfeld A, Huggins J, Hortal S, Anderson I, et al. Plant-mediated partner discrimination in ectomycorrhizal mutualisms. Mycorrhiza. 2019;29:97-111.

76. Hortal S, Plett KL, Plett JM, Cresswell T, Johansen M, Pendall E, et al. Role of plant-fungal nutrient trading and host control in determining the competitive success of ectomycorrhizal fungi. ISME J. 2017;11:2666-76.

77. Vellend M. Conceptual synthesis in community ecology. Q Rev Biol. 2010;85:183-206.

78. Nicholson BA, Jones MD. Early-successional ectomycorrhizal fungi effectively support extracellular enzyme activities and seedling nitrogen accumulation in mature forests. Mycorrhiza. 2017;27:247-60.

79. Marupakula S, Mahmood S, Jernberg J, Nallanchakravarthula S, Fahad ZA, Finlay RD. Bacterial microbiomes of individual ectomycorrhizal Pinus sylvestris roots are shaped by soil horizon and differentially sensitive to nitrogen addition. Environ Microbiol. 2017;19:4736-53.

80. Cullings K, Ishkhanova G, Henson J. Defoliation effects on enzyme activities of the ectomycorrhizal fungus Suillus 
granulatus in a Pinus contorta (lodgepole pine) stand in Yellowstone National Park. Oecologia. 2008;158:77-83.

81. Jones MD, Phillips LA, Treu R, Ward V, Berch SM. Functional responses of ectomycorrhizal fungal communities to long-term fertilization of lodgepole pine (Pinus contorta Dougl. ex Loud. var. latifolia Engelm.) stands in central British Columbia. Appl Soil Ecol. 2012;60:29-40. 